\title{
Firm Characteristics and Long-Run Abnormal Returns after IPOs: A Jordanian Financial Market Experience
}

\author{
Fawaz Al-Shawawreh $^{1} \&$ Osama Al-Tarawneh ${ }^{1}$ \\ ${ }^{1}$ Finance and Banking Department, Faculty of Business Administration, Mutah University, Karak, Jordan \\ Correspondence: Fawaz Al-Shawawreh, Finance and Banking Department, Faculty of Business Administration, \\ Mutah University, Karak, P.O. Box (7), 61710, Jordan. E-mail: fawaz_shawawreh@yahoo.com
}

Received: November 24, 2014

Accepted: December 25, 2014

Online Published: February 25, 2015

doi:10.5539/ijef.v7n3p109

URL: http://dx.doi.org/10.5539/ijef.v7n3p109

\begin{abstract}
This study aims to detect the long run performance of the Jordanian initial public offerings (IPOs) listed in Amman stock exchange during the period from (1st January, 1993 until 31st December, 2011). In order to achieve the study's objectives, the researcher applied "The Event Study" approach on the study sample which is consisted of all the Jordanian initial public offerings that are listed in Amman stock exchange during the study period, which were (119) companies. We calculated the monthly returns of these companies for 60 months (5 years) after listing. Also, a simple linear regression model applied to explore the relationship between the companies' characteristics such as (company age, size, the sector in which the company belongs, and the offer size), and the abnormal return (AR) by using the three benchmarks that are employed in the study. The results of the analysis showed that the study corresponds to most of the previous studies with regard to the long run underperformance phenomenon for the initial public offerings (IPOs), but the level of this underperformance was different based on the benchmark employed to measure the long run performance. This conclusion was also confirmed by some previous studies. This study showed that there are statistically significant differences in the abnormal returns (AR) after applying the three benchmarks by using the parametric "One Sample T-test". Finally, by running simple linear regressions, the study showed that there is statistically significant positive relationship between the characteristics of the firm (size, age, sector, and offer size) and the abnormal return (AR) after applying various benchmarks.
\end{abstract}

Keywords: Initial Public Offerings (IPOs), long run underperformance, firm characteristics, event study

\section{Introduction}

Many empirical studies have been conducted to examine the efficient market theory. Some of these studies indicated to the presence of a number of anomalies in the behavior of stock prices in long-term performance. They documented that the impact of these anomalies is mainly related to the firm' characteristics, like the size of the firm, the age, the offer size, and the sector. Some of researchers found that the shares return of small companies is higher than the shares return of large ones.

This research comes as a complement to the previous studies to see if there is an effect of the firm's characteristics on stock performance in the long term for the industrial IPO firms listed in the Amman stock market. This research is a cross-sectional analysis study to measure the performance of the long-term abnormal returns of Jordanian initial public offers (IPOs) listed in Amman Stock Exchange (ASE) during the period (1993-2011) using various indexes. In light of this, the problem of the research is summarized as investigating the relationship between abnormal returns in the long-term and the firm characteristics such as size, age, sector and the size of offers for the firms listed in Amman Financial Market. The research will seek to answer several questions like, if the long run abnormal return (AR) is sensitive to the benchmark employed, and if the long run abnormal return (AR) is affected by the features of IPOs firms (age, size, scoter, and the offer size)?

In this study, we assess further abnormal returns reported after corporate events. However, any study of abnormal returns must compare realized returns to a benchmark model of normal returns. Our collective understanding of normal returns remains imperfect, which is the "bad model problem" discussed by Fama (1998). While imperfect assessment of normal benchmark returns is of a minor importance over short horizons such as few days, the issue can be of first order importance over the horizons considered in long-run return studies. Moreover, this study is seeking to find out how Jordanian IPOs performed in the long run - relative to certain benchmarks employed. 


\section{Previous Literature}

A seminal article by Ibbotson (1975) reported a negative relation between initial Returns at the IPO and long-run share price performance for a sample of US IPOs issued during the period 1960-1969. He reported that there was a general positive Performance in the first year, negative performance in the next three years and a general positive performance in the fifth year.

Dimson and Marsh (1986), Ritter (1991), Gregory et al. (1994) and Fama and French (1996) and Fama (1998) among others demonstrated that the measurement of the long-run performance of the IPOs is sensitive to the benchmark employed. So the possibility remains that imperfect benchmarking lies behind the poor long-run returns.

Ritter (1991) analyzed the performance of (1,526 US IPOs) issued between (1975-1984) and reported underperformance of the benchmarks (NASDAQ, AMEX, NYSE) by about $-27.39 \%$ in the three-year period after issuance. He also found that there are significant relationships between the age of the firms listed and their long run performance. Fama and French (1992) analyze all non- financial US IPO firms issued during the period (1962-1989). They exclude financial firms because the high leverage that is normal for these firms probably does not have the same meaning for non-financial firms. They study the joint roles of market Beta $(\beta)$, size, E\P, leverage, and book - to-market equity in the cross - section of average stock return. They find that being used alone or in combination with other variable ( the slope in the regression of a stock return on a market return ) has little information about average return, size, E/P, leverage, and book to market equity have explanatory power. In combination size, book to market equity seem to absorb the apparent roles of leverage and E/P (earning / price) in average return. Also Fama and French document that common stock returns are related to firm size and book to market ratio.

Levis (1993) investigated the long run performance of a sample consisting of (712 UK IPOs) issued during (1980-1988). He reported that a long run return is based on three alternative benchmarks: the financial time actuaries all share index (FTAI), the Hoar Govett small companies index (HGSCI),and all share equally weighted index(ASEWI). His work confirmed the findings of the long run underperformance in the (UK) market between $8 \%$ to $23 \%$ depending on benchmark used. Levis also confirms Ritter (1991) findings of statistically significant long run IPOs underperformance. Loughran and Ritter (1995) examined a sample of 4,753 US IPOs issued during (1970-1990), Loughran and Ritter report that whether initial public offerings (IPOs) or seasoned equity offerings (SEOs) are significantly underperformed relative to non-issuing firms for five years after the offering date, the average annual return during the five years after issuing is only $5 \%$ for firms conducting IPOs, and only $7 \%$ for firms conducting SEOs.

Barber and Lyon (1997) analyzed 1,798 US IPOs issued during July 1963 to December 1994 using CAR and BHAR, Fama and French three -factors model. They reported three worthy results; firstly, cumulative abnormal return calculated using reference portfolios yield test statistics that are positively biased. The magnitude of the bias increases with the horizon of accumulation. This positive bias can be attributed to the positive mean abnormal return, which results from the new listing bias. Note that this positive bias is most pronounced when an equally weighted market index is used to calculate the CAR. Secondly, all of the control firm approaches yield well specified test statistics, the only exception for that is the size-matched control firm approach at the $5 \%$ significance level and 36 month. Finally, Barber and Lyon document that Fama-French three factor model yields negatively biased test statistics at 12 - and 36- month horizon.

Brav and Compers (1997) report that venture capital - backed IPOs; unlike other IPOs in the US; do not significantly underperform over the long term relative to a style benchmark, suggesting that reputational concerns may constrain their actions. Reputational concerns may also be responsible for the fact that potential conflicts of interest on the part of venture capitalists appear to play a little role in the pricing and performance of US IPO (Gompers \& Lerner, 1999).

Desai and Jain (1997) and IKenberry et al. (1996) find that the firm that spilt their stock experience long term positive abnormal returns both before and after the spilt. They attribute the post-split returns to market under reaction to the positive information signaled by spilt.

Fama and French (1998) document that the long term returns anomalies are fragile; they tend to disappear with reasonable changes in the way they are measured. Fama and French (1996) discuss the quarrels with their multi-factor model, but their results suffice to illustrate, the important point here is that inference about market efficiency can be sensitive to the assumed model for expected returns.

Espenlaub et al. (1998) reexamined the evidence of the Long run return of IPO in UK over the period 
(1986-1991) like Levis by using a number of alternative benchmarks and confirmed that in the Long run the IPO firms underperform the market.

Barber, Lyon, and Tsia (1999) analyzed all NYSE/AMEX/NASDAQ firms during the period from July 1973 through December 1994.They analyzed various methods to test long run abnormal stock returns and investigated misspecification. As a result, they document that misspecification can be traced to (1) the new listing bias (2) the rebalancing bias (3) the skewness bias (4) cross sectional dependence and or (5) Bad model of asset pricing. How and whether these factors affect the misspecification of test statistics depend on the method used to calculate the abnormal returns.

Khurshed (1999) used a sample consisting of 240 UK IPOs issued during 1991-1995 and covering $95 \%$ of the total number of new issues. He has found a positive relationship between the (size) of the firm and its long run performance. (the Larger size of the firm, in terms of the assets at the time of flotation, the better Long run performance of IPO will be). Also, contrary to the findings of Ritter (1991) and Carter (1998) he does not find any relationship between the age of the firm and the underwriter reputation and the long run performance of IPO. They showed that long-run performance is positively related to the degree of multi-nationality of a firm. They found a significant negative relationship between the long-run performance and first day returns. The quality of a firm at the time of the IPO also explains long-run performance. The better the quality the less is the underperformance. In addition to these, they reported three more interesting results. First, the more profitable the company is before flotation, the worse is its long-run performance. Second, the larger the size of the firm the better is the long-run performance. Third, the greater the change in the ownership structure at the time of offering (i.e., the greater the extent of original shareholders' dilution of ownership at the time of offering), the worse is the long-run performance. Interestingly, unlike previous research, they do not find a statistically significant direct relationship between the age of a firm and its long-run performance. This is also the case with the reputation of the underwriter.

Espenlaub and Gregory (2000) investigate a sample consisting of (588) UK IPOs issued during the period form (1985-1992) using more than benchmarks (CAPM, value weighted multiple index, Fama and French model, size decile model), the results confirm the existence of statically and economically significant long run IPOs under performance irrespective of the benchmark employed. Mitchell and Stafford (2000) analyzed a sample consisting of major managerial decisions, namely: mergers SEOs, share repurchases completed during the period (1958-1993). The sample consists of 4,911 underwritten primary and combination seasoned equity offerings (SEOs); 2,421 open market and tender - offer share repurchases and; 2,193 acquisitions of CRSP in the UK using BHAR model. They found that the popular approach of measuring long-term abnormal performance with mean BHARs in conjunction with bootstrapping is not an adequate methodology because it assumes independence of multi-year event firm abnormal returns. Also they showed that event firm abnormal returns are positively cross-correlated when overlapping in calendar time. As such assuming independence is problematic for any long term abnormal performance methodology. Moreover, this is likely to be a problem for most event samples, not just the mergers, SEOs, and share repurchases examined in this paper.

Sapusek (2000) analyzes the long run performance of (142) German IPOs issued during the period (1983-1993) compared with various benchmark-index and matching firm. The result in this study reported that the long run performance depends to a great extent on the benchmark used and the period analyzed.

Gompers and Lerner (2001) examine the performance for five years after listing using a sample consisting of $(3,661)$ US IPOs issuing from 1935 to 1972 . The sample displays some underperformance when event-time buy and hold abnormal returns are used to calculate abnormal return. The underperformance disappears, however, when cumulative abnormal returns are utilized. A calendar time analysis shows that over the entire period, IPOs return as much as market. The intercepts in CAPM and Fama French regressions are insignificantly different from Zero, suggesting no abnormal performance.

Kooli and Suret (2004) investigate the long run performance of (445) Canadian IPOs issued during the period (1991-1998).They found that investors who buy immediately after listing and who hold shares for five years will incur a loss of $24.66 \%$ on an equally weighted basis or $15.16 \%$ on a value weighted basis relative to an investment in the control firms. Also they found that IPOs underperformed over five years but the significant result varied according to the models used.

Drobetz et al. (2005) analyzed a sample consisting of 109 Swiss IPOs issued during the period (1983-2000).He found that the average market adjusted initial return is $34.97 \%$.To examine the long run performance of Swiss IPOs, he compute the buy and hold returns, Skewness adjusted wealth ratio, cumulative abnormal returns, he found that Swiss IPO underperformed over four years. 
Dimovski and Brooks (2008) examined 100 Australian gold mining IPOs which is considered as an important industry sector to the Australian stock exchange from (1979-1990) and reported an average excess returns of $119.51 \%$ by those IPOs. The same researchers updated that analysis by investigating 114 Australian gold mining IPOs from 1994-2004 and they found significantly lower average first day return equivalent to $13.3 \%$. Such a change is due to different legislative setting and institutional environments compared to more recent years. Braik (2010) investigated a sample consisting of (53) firms that went public in ASE over the period (1999-2008) using the general free float index (GFFI), the sector free float index (SFFI), and the value weighted index (VWI) as a benchmarks ; Braik found out that the data support the fads hypotheses, but refuse the windows of opportunity hypotheses. The study also suggests some evidence of the prospect of some operating determinants like, offer size, and SEOS to explain the Jordanian IPOS underperformance.

Gregory, Cuermat, and Al-shawawreh (2010) examined 2,499 UK IPOs Issued between mid-1975 and the end of 2004, they found compelling evidence of long run underperformance that persists for between 36 and 60 months post flotation, depending on the precise method chosen to measure abnormal returns.

Agarwal (2012) examined the stock price reaction to announcement of 205 rights offers of equity in India made during the period from April 2000 to March 2011; the results of this study are consistent with those observed in developing countries which show that the abnormal returns observed around the announcement date hold a negative relationship with the decrease in leverage and the price discount offered in the rights issue.

In this study, we are not directly concerned in understanding and explaining long-term underperformance as far as we interested in recognizing measurable firm characteristics at the time of IPO that are associated with long-term performance in a methodical way. The characteristics that we inspect are based on theoretical considerations, supported by previous research on IPOs as well as the more general theory of the firm.

In this study we hypothesise that the long-run performance of the IPOs is a function of the managerial decisions and performance of the firm after going public. To test this proposition, we have used a number of characteristics of the firms in our sample. These characteristics have been used as proxies for size of the firms, proxy for age of the IPO, proxy for size of offers and proxy for sector where the firms belong to.

\section{Null Hypotheses}

The normal return has been computed for the sample of the study, afterward we compared this return in the long run with the appropriate benchmark employed to measure the abnormal return (AR). Based on that, a set of null hypotheses developed to test if the abnormal return is statistically different from zero. Furthermore, we developed another set of null hypotheses to observe the relationship between the abnormal return of IPOs firms and the firm characteristics represented by firm size, age, size of offers, and sector at the significant level of $(5 \%)$. Table (1) summarized the research null hypotheses.

Table 1. Research Null hypotheses

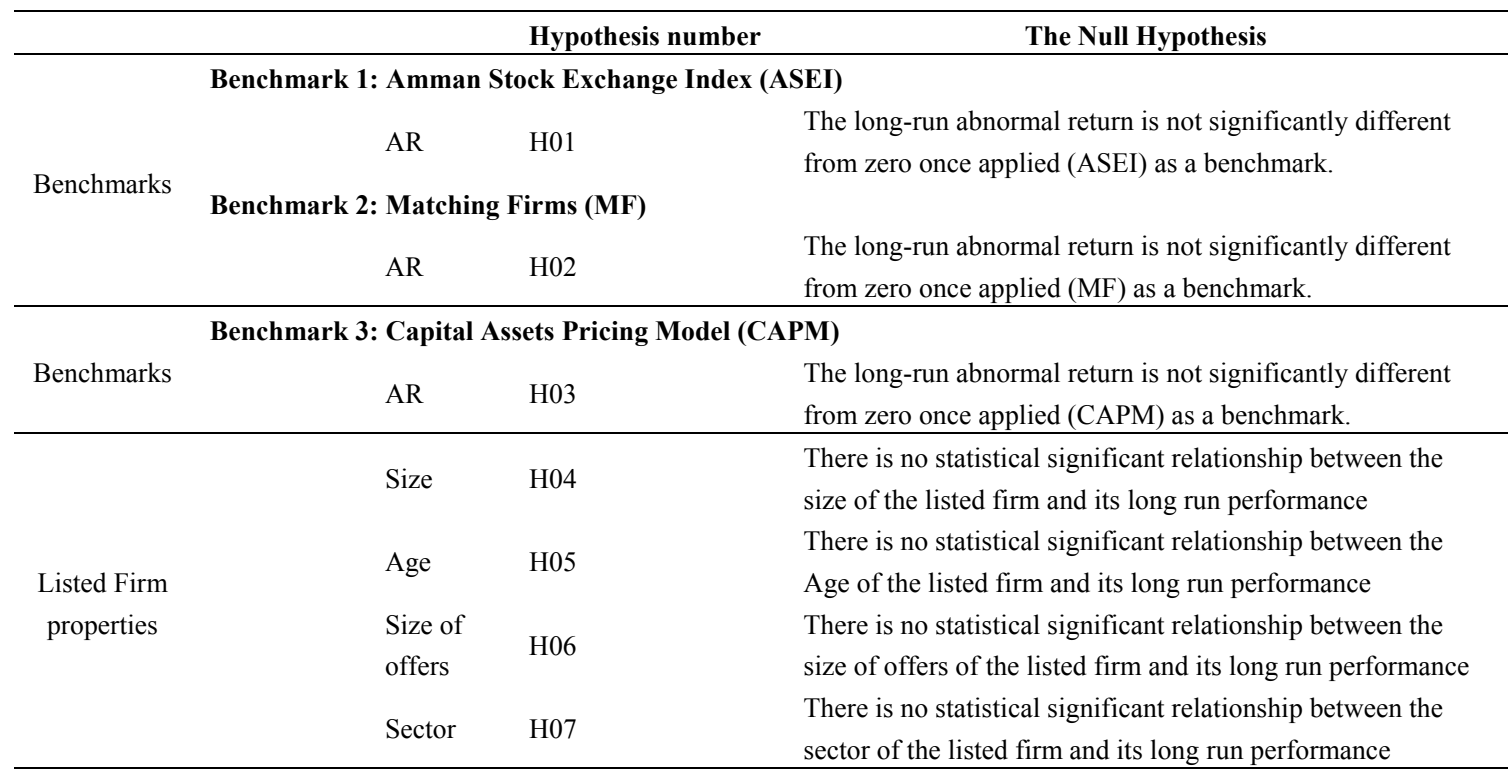




\section{Research Methodology}

Three benchmarks have been employed in this study to assess the abnormal returns (AR).

i) Capital assets pricing model (CAPM): In this benchmark, IPOs firms' monthly returns have to be computed during the study period $\left(R_{i t}\right)$. Furthermore, the monthly risk free rate of returns $\left(R_{F t}\right)$ represented by Treasury bill returns have been collected from the ministry of finance and central bank of Jordan. The market monthly return during the study period $\left(R_{m t}\right)$ is detected based on Amman stock exchange general index weighted by market capitalization. The appropriate formula for calculating the abnormal return (AR) according to this benchmark will be as follows (Gregory \& Espenlaub, 2000):

$$
A R^{C A P M}=R_{i t^{-}}\left[R_{F t}+\beta\left(R_{m t}-R_{F t}\right)\right]
$$

Where:

$R_{i t}=$ is the return of company (IPOs) in event month $\mathrm{t}$;

$R_{m t}$ : is the return of market in event month t.as measured by (ASE) index;

$R_{F t}$ : is the Treasury bill return in event month $\mathrm{t}$;

$B:$ is the CAPM beta measured as.

ii) Matching firms (MF): According to this benchmark, the IPOs returns are matched with a non IPO firm return, which has asimilar market capitalization, and (similar age, or belong to the same sector) if possible. But if they are not similar, the comparison will be made between the IPO firms and the non IPO firms which may have closer characteristics of size and age, and regardless of the sector. The abnormal return (AR) according to the benchmark will be as follows:

$$
A R^{M F}=R_{i t}-R_{M F}
$$

Where:

$R_{i t}$ : is the return of company $\mathrm{i}$ in event month $\mathrm{t}$;

$R_{s t}$ : is the return of size control portfolio in event month $\mathrm{t}$, in this bench mark, the control portfolio return are equally weighted average return on a portfolio of all firm in the market capitalization decline to which firm $\mathrm{i}$ belongs in a given sample year.

iii) Amman Stock Exchange index (ASE index): The third benchmark employed in this study is the Amman stock exchange index represented by the general index weighted by market capitalization. According to this benchmark, the comparisons will occur between the firms listed returns and (ASE) index itself.

$$
A R^{A S E I}=R_{i t}-R_{m t}
$$

\subsection{Regression Models}

Khurshed et al. (1999) documented that the cross sectional study of long-run returns revealed that the larger firms perform better in the long run. This result is similar to Levis (1993) conclusions. While Levis used the gross proceeds from the offering as a proxy for size, Khurshed use two other variables (ASSFLOAT and MCAPFLOT) and expect them to have positive coefficients and hypothesize "There is a positive relationship between the size of a firm, the age, the underwriter reputation at the time of its going public and its long-run share price performance after the IPO".

Khurshed (1999) make the following four assumptions:

(1) Bigger firms are better quality firms;

(2) Bigger firms raise larger amounts of capital from their listing;

(3) Bad quality firms are bad long term performers;

(4) Assumption (3) is known to the underwriter and hence this information is reflected in the cost of underwriting.

We follow Khurshed et al. (1999) to test the relationship between firm characteristics and long run abnormal return by added another two variables. In addition to the firm size, age, we want to explore the effect of size of offers, and sectors on the long run performance. A simple linear regressions is constructed to examine the relationship between the listed IPOs firm characteristics (age, size, sector, size of offers), and the long run abnormal return (AR) among the three benchmarks employed. According to this model, the dependent variable is the (abnormal return using the three benchmarks, ASEI, MF and CAPM) and the independent variable as 
represented by the IPOs firm characteristics. The equations below reflect these relationships:

$$
\begin{array}{r}
A R_{A S E I}=\alpha+\widehat{\beta}_{1} X_{\text {age }}+e \\
A R_{A S E I}=\alpha+\widehat{\beta}_{2} X_{\text {size }}+e \\
A R_{A S E I}=\alpha+\widehat{\beta}_{3} X_{\text {sector }}+e \\
A R_{A S E I}=\alpha+\widehat{\beta}_{4} X_{\text {offer size }}+e \\
A R_{M F}=\alpha+\widehat{\beta}_{1} X_{\text {age }}+e \\
A R_{M F}=\alpha+\widehat{\beta}_{2} X_{\text {size }}+e \\
A R_{M F}=\alpha+\widehat{\beta}_{3} X_{\text {sector }}+e \\
A R_{M F}=\alpha+\widehat{\beta}_{4} X_{\text {offer size }}+e \\
A R_{C A P M}=\alpha+\widehat{\beta}_{1} X_{\text {age }}+e \\
A R_{C A P M}=\alpha+\widehat{\beta}_{2} X_{\text {size }}+e \\
A R_{C A P M}=\alpha+\widehat{\beta}_{3} X_{\text {sector }}+e \\
\mathrm{AR}_{\mathrm{CAPM}}=\alpha+\widehat{\beta}_{4} \mathrm{X}_{\text {offer size }}+\mathrm{e}
\end{array}
$$

The tables below summarize the main variables in this study. Panel (A) explains the benchmarks, and the models used to measure the long run performance of Jordanian IPOs. While panel (B) shows the firms' characteristics that will be investigated in order to explain the relationship between these variables and the IPOs firm's abnormal return.

Each variable is defined below.

Table 2. Definition of the variables related to Jordanian's IPO performance

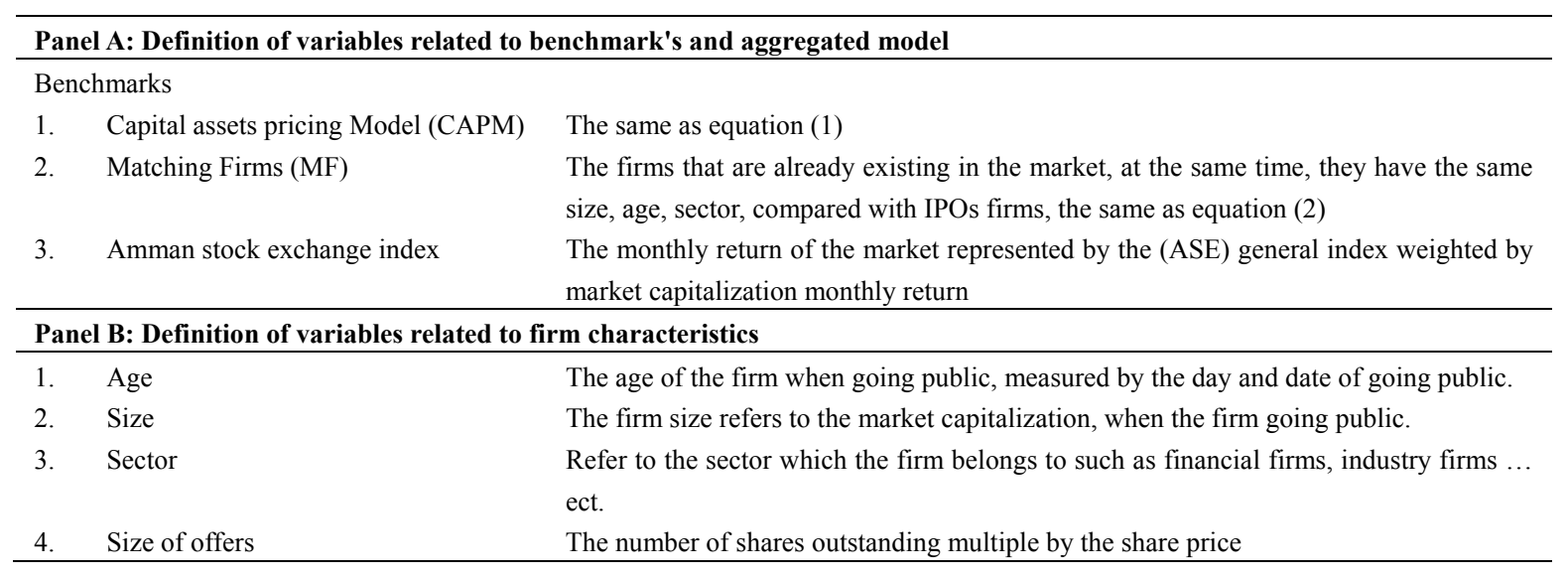

\section{Sample of the Study}

We compile a sample of pure initial public offerings from ASE database firms, between 1993 and 2011. In order to remain in the final sample, a firm must satisfy the following Criteria:

1) The common stock is listed on ASE and has security returns for at least 12 month and extended up to 60 months.

2) The listing of the company's shares is not suspended during the tested period.

3) The security is not a real estate investment trust, financial, and insurance firms.

4) Firms that changed their legal status from limited liability companies to public shareholders companies are excluded.

5) Privatized firms are excluded.

The population of the study sample is 188 firms, 119 firms met the criteria mentioned above. The raw data has been collected from many sources such as Jordan Securities Commission (JSC) annual reports, Amman Stock Exchange 
(ASE) annual report, and Central Bank of Jordan (CBJ).

Each IPO firm returns have been calculated based on the closed price at the end of every month. This return tracked up to five years after listing depending on the availability of the return in each month.

The index return represents Amman Stock Exchange (ASE) general weighted index, thus, the index return traced also up to the five years matching the window period of the sample. Also, the matching firms return collected from (JSC) as a daily closing price is converted into the monthly returns in order to achieve the research objectives.

\section{Jordanian IPO's Market}

The Jordanian IPO market consists primarily of the start-up companies, the offering price of a newly established company is set by the Jordanian Securities Commission (JSC) at its par value of (1JD) due to the relatively low number of IPO in the market and the degree of attractiveness to investors.

Table 3. Descriptive of Jordanian IPOs market

\begin{tabular}{cccc}
\hline Year & Number of IPOs & Number of IPOs \% & Offer value (million JD ) \\
\hline 1993 & 11 & $9.2 \%$ & 71.65 \\
1994 & 19 & $16 \%$ & 153.4 \\
1995 & 14 & $11.8 \%$ & 134.4 \\
1996 & 6 & $5 \%$ & 39.0 \\
1997 & 1 & $0.8 \%$ & 2.0 \\
1998 & 2 & $1.7 \%$ & 20.62 \\
1999 & 1 & $0.8 \%$ & 2.2 \\
2000 & - & - & - \\
2001 & 1 & $0.8 \%$ & 0.100 \\
2002 & 1 & $0.8 \%$ & 11.5 \\
2003 & - & - & - \\
2004 & - & - & - \\
2005 & 9 & $7.6 \%$ & 68.7 \\
2006 & 16 & $13.4 \%$ & 359.4 \\
2007 & 17 & $14.3 \%$ & 416.9 \\
2008 & 13 & $11 \%$ & 240.5 \\
2009 & 1 & $0.8 \%$ & 3.0 \\
2010 & 5 & $4.2 \%$ & 41.0 \\
2011 & 2 & $1.7 \%$ & 57.5 \\
Total & 119 & $100 \%$ & $1,621,875 \mathrm{JD}$ \\
\hline
\end{tabular}

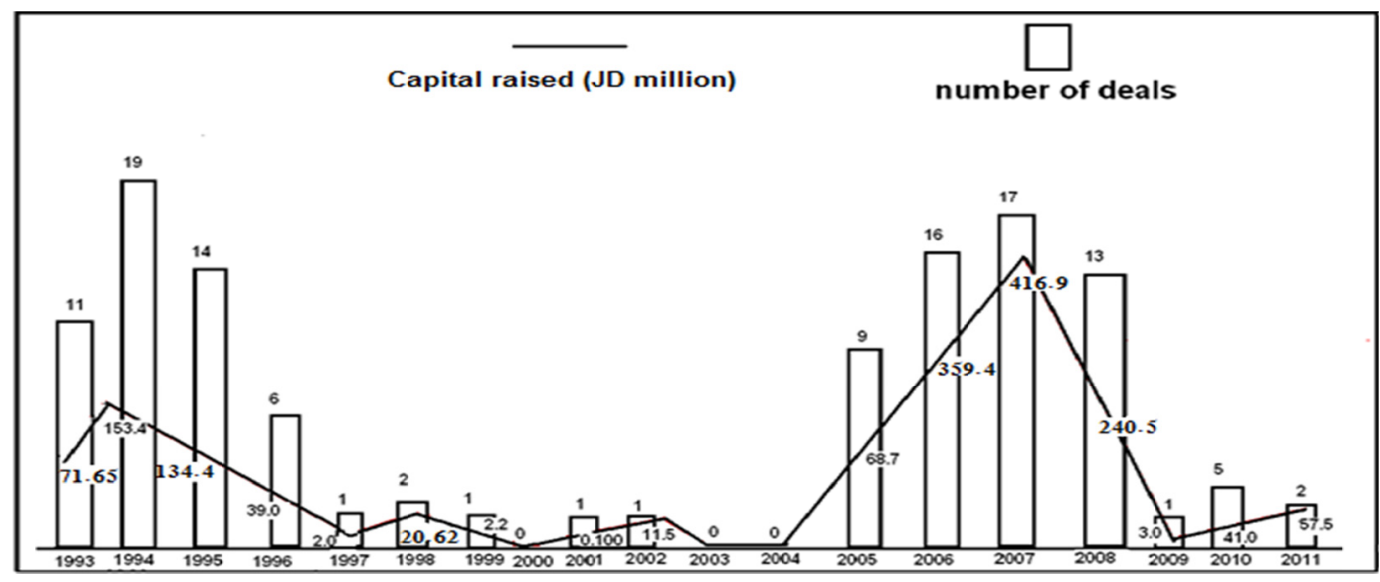

Figure 1. Jordanian IPO activity during (1993-2011)

During the study period, the Jordanian IPOs market witnessed fluctuation in the number of IPOs, In some years there could be one, or two, or none, in other years we may find 10, or more. For example there are no IPOs in years 2000, 2003, 2004, may be as a result of falls in market indices and the war of Iraq. This tendency is 
consistent with the notion of the hot issue market of (Ritter, 1984). As result, the years 2000, 2003, 2004 are representing cold periods where, the years 2005, 2006, 2007, 2008 representing hot periods. The total number of IPOs in Jordan equity market (after excluding the private offerings plus firms that change their status plus privatized firms) during the study period (1993-2011) is 119 IPOs (which represent the sample of study).See table (1) and figure (1). Where the total Jordanian Dinar raised through these IPOs for the same period reached an approximate amount of 1,621,875. JD.

In the beginning of the nineties, the stock market became more attractive and had a lot of IPOs. For example in 1994 there were (19) companies listed in the ASE and in 1995 there were (14) companies listed in the ASE, and (11) companies listed in ASE in 1993. This activity is due to the market as a result of several factors including the future expectation for Jordanian economy after signing on the peace agreement on 26 October 1994 as well as the great activity in the secondary market during the period from 1991 to 1993 which was accompanied by a rise in stock prices, and encouraged the establishment of new companies and encouraged the companies which were already existing in the market to increase their capital by offering new shares for subscription.

\section{Test of Significance of Abnormal Return (AR)}

After Abnormal Return (AR) is calculated against the employed benchmarks (CAPM, MF, and ASEI), the parametric one sample t-test is used to examine whether the obtained average abnormal return (AR) is significantly different from zero at significant level $(\alpha \leq 5 \%)$ :

$\mathrm{H}_{01}: \mathrm{AR}_{\text {sample, } \mathrm{ASEI}}=0$ against $\mathrm{H}_{01}: \mathrm{AR}_{\text {sample, } \mathrm{ASEI}} \neq 0$;

$\mathrm{H}_{02}: \mathrm{AR}_{\text {sample, } \mathrm{MF}}=0$ against $\mathrm{H}_{02}: \mathrm{AR}_{\text {sample, } \mathrm{MF}} \neq 0$;

$\mathrm{H}_{03}: \mathrm{AR}_{\text {sample,CAPM }}=0$ against $\mathrm{H}_{03}: \mathrm{AR}_{\text {sample,CAPM }} \neq 0$.

In order to investigate the effect of the firm's characteristics on the abnormal return (AR), a simple linear regression model is constructed to find out how these factors are correlated with the abnormal return (AR) based on the three employed benchmarks. So, the null hypothesis below will be tested based on the regression result at significant level $(p \leq 5 \%)$.

$\mathrm{H}_{04}: p_{\text {firm size, } \mathrm{AR}} \leq 5 \%$ against $\mathrm{H}_{1,4}: p_{\text {firm size, } \mathrm{AR}}>5 \%$;

$\mathrm{H}_{05}: p_{\text {firm age, } \mathrm{AR}} \leq 5 \%$ against $\mathrm{H}_{1,5}: p_{\text {firm age, } \mathrm{AR}}>5 \%$;

$\mathrm{H}_{06}: p$ size of offers, $\mathrm{AR} \leq 5 \%$ against $\mathrm{H}_{1,6}: p_{\text {size of offers, } \mathrm{AR}}>5 \%$;

$\mathrm{H}_{07}: p$ sector of firm, $\mathrm{AR} \leq 5 \%$ against $\mathrm{H}_{1,7}: p_{\text {sector of firms, } \mathrm{AR}}>5 \%$.

\section{Empirical Results and Analysis}

The Jordanian IPOs monthly returns are calculated. Also, each bench mark (Index, MF, CAPM) monthly returns are calculated to make the comparison and to calculate (AR) for the Jordanian Initial Public Offerings (IPOs). So, the discussion will be based on each benchmark results, to analyze the long run performance of Jordanian initial public offerings.

8.1 Descriptive Statistics for (AR)

A statistical description of (AR) of the three benchmarks employed in this study is presented in Table 3 below:

Table 4. Descriptive statistics of long term Jordanian IPOs returns

\begin{tabular}{|c|c|c|c|c|c|c|}
\hline & $\mathbf{N}$ & Minimum & Maximum & Mean & Median & Std.Dev \\
\hline \multicolumn{7}{|c|}{ Panel (A): ASEI (Benchmark number one) } \\
\hline AR & 60 & -0.0262 & 0.0211 & 0.01258 & 0.0010 & 0.0063 \\
\hline \multicolumn{7}{|c|}{ Panel (B): MF (Benchmark number Two) } \\
\hline AR & 60 & -0.0361 & 0.0032 & 0.00348 & 0.0192 & 0.0064 \\
\hline \multicolumn{7}{|c|}{ Panel (B): CAPM (Benchmark number Three) } \\
\hline $\mathrm{AR}$ & 60 & -0.0600 & 0.0031 & 0.0055 & 0.0043 & 0.0127 \\
\hline
\end{tabular}

\subsection{Long Run Performance of Jordanian Initial Public Offering}

The analysis of long run performance of Jordanian (IPOs) will be based on output from each benchmark employed to explain and describe the performance of Jordanian (IPOs) in the long term. 


\subsubsection{Benchmark 1: Amman Stock Exchange Index (ASEI)}

The (AR) related to this benchmark is calculated. Table (4) shed light on these values during particular windows of time. Figure (1) shows the changes of the abnormal return of (AR) among the entire period using (ASEI) as the first benchmark.

Table 5. (AR) Using (ASEI) as a benchmark

\begin{tabular}{cc}
\hline Month of intervals & $\mathbf{A R} \%$ \\
\hline 6 & -0.008 \\
12 & -0.007 \\
24 & -0.023 \\
36 & -0.019 \\
48 & -0.019 \\
60 & -0.013 \\
\hline
\end{tabular}

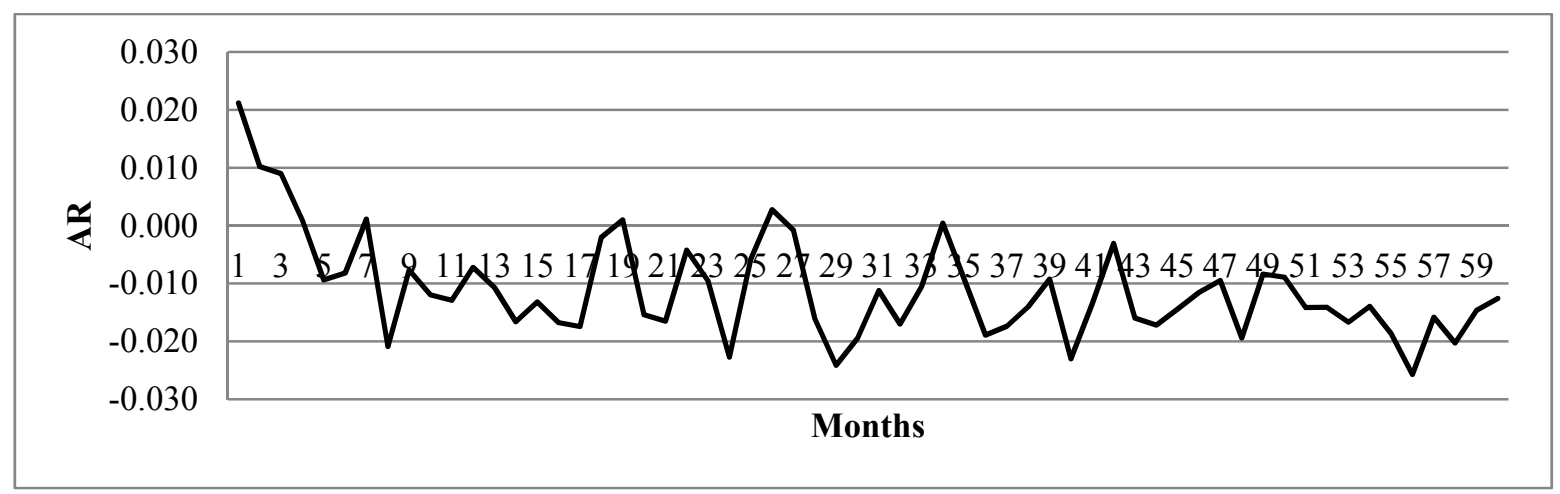

Figure 2. Abnormal Return (AR) using (ASEI) as a benchmark

\subsubsection{Benchmark 2: Matching Firms (MF)}

Table 6. (AR) Using (MF) as a benchmark

\begin{tabular}{cc}
\hline Month of intervals & AR\% \\
\hline 6 & -0.001 \\
12 & -0.001 \\
24 & -0.002 \\
36 & -0.002 \\
48 & -0.002 \\
60 & -0.004 \\
\hline
\end{tabular}

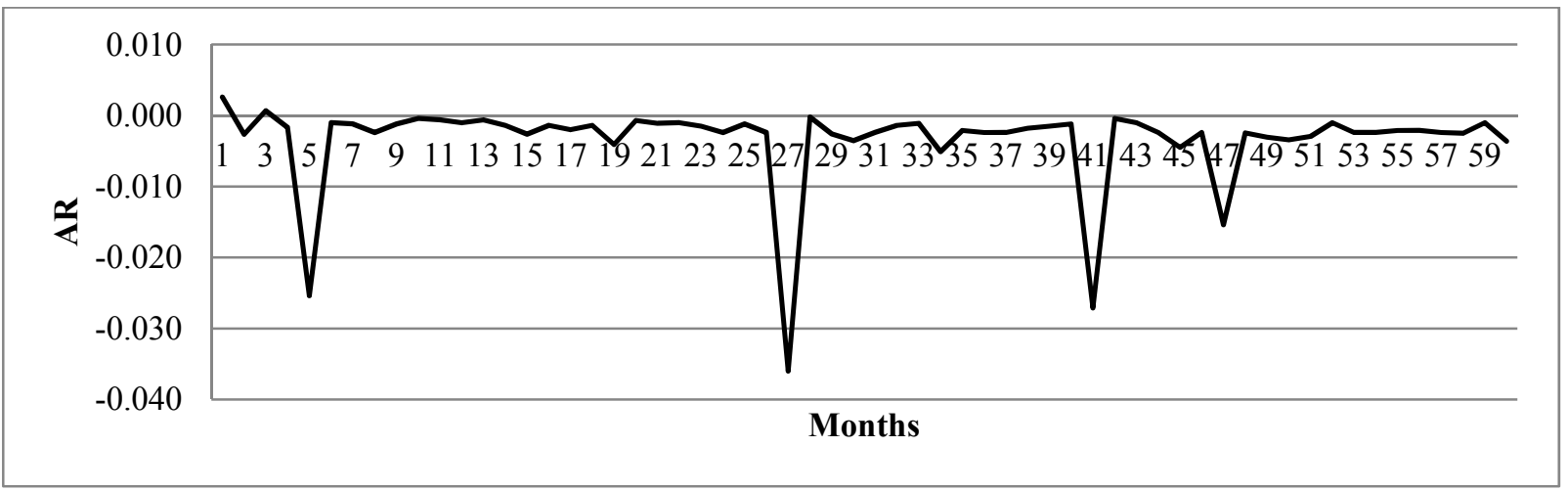

Figure 3. Abnormal Return (AR) using (MF) as a benchmark 
After calculating the monthly return of the matching firms during the study period, we calculate (AR) for this benchmark. Table 5 shed light on these values after six months, one year, two years, three years, four years, and five years after going public. Figure 8 shows the changes of (AR) among the entire period using (MF) as the second benchmark.

\subsubsection{Benchmark 3: Capital Asset Pricing Model (CAPM)}

The last benchmark employed in this study to measure the long run performance of Jordanian (IPOs) is the Capital Assets Pricing model (CAPM). Table 6 and Figure 12 show the results of (AR) along the time using this benchmark.

Table 7. (AR) Using (CAPM) as a benchmark

\begin{tabular}{cc}
\hline Month of intervals & $\mathbf{A R} \%$ \\
\hline 6 & -0.002 \\
12 & -0.001 \\
24 & -0.004 \\
36 & 0.001 \\
48 & -0.001 \\
60 & -0.002 \\
\hline
\end{tabular}

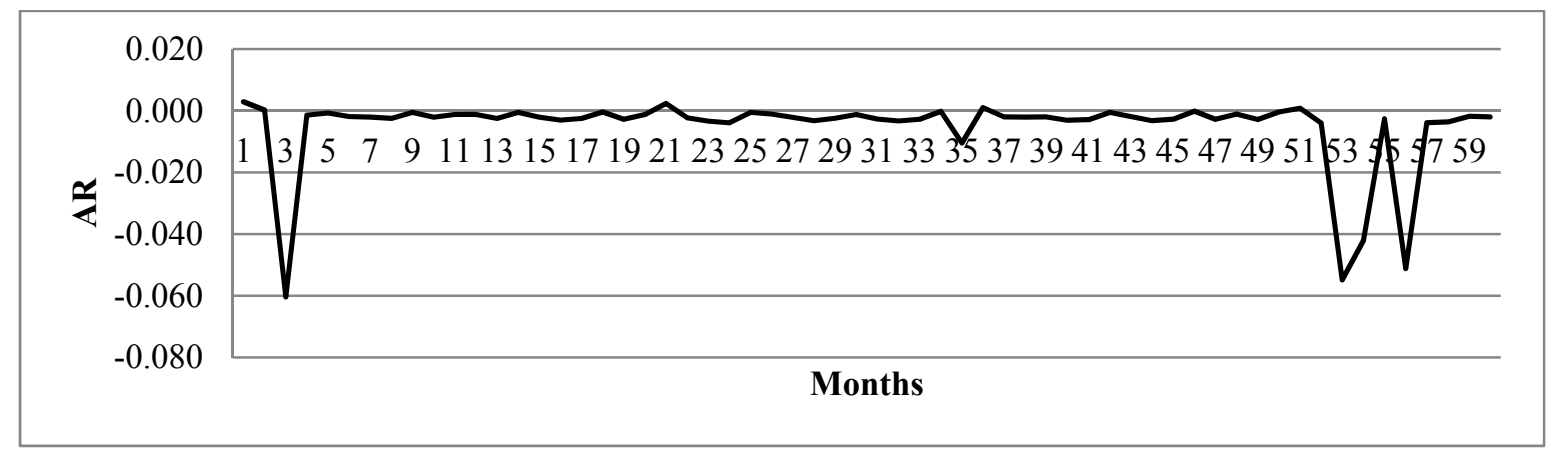

Figure 4. Abnormal Return (AR) using (CAPM) as a benchmark

Table 6 and Figures 3 above, show that the Jordanian (IPOs) after six months of going public underperformed against this benchmark by about $(-5.9 \%)$ which represent the value of cumulative abnormal return after six months of trading. The level of underperformance increased at the end of the first year, second year, and third year up to $(-6.9 \%,-9.1 \%,-12 \%)$ respectively and rose again at the end of the period up to $(-14.5 \%,-31.3 \%)$ at the end of the fourth year, fifth year respectively.

\section{Parametric T-test}

Table 8. One sample statistics and T-test for the (AR) using different benchmark

\begin{tabular}{|c|c|c|c|c|c|c|}
\hline \multicolumn{7}{|c|}{ Panel A. AR using ASEI as a benchmark } \\
\hline \multirow{3}{*}{$\mathrm{AR}$} & \multirow{2}{*}{$\mathrm{N}$} & \multirow{2}{*}{ Mean } & \multirow{2}{*}{ Std.dev } & \multicolumn{3}{|c|}{ t-statistic } \\
\hline & & & & df & Value & probability \\
\hline & 60 & 0.01258 & 0.006384 & 59 & 15.268 & $0.0000 * * *$ \\
\hline \multicolumn{7}{|c|}{ Panel B. AR using MF as a benchmark } \\
\hline \multirow{3}{*}{ AR } & \multirow{2}{*}{$\mathrm{N}$} & \multirow{2}{*}{ Mean } & \multirow{2}{*}{ Std } & \multirow{2}{*}{ df } & \multicolumn{2}{|c|}{ t-statistic } \\
\hline & & & & & Value & probability \\
\hline & 60 & 0.00348 & 0.006400 & 59 & 4.216 & $0.0000 * * *$ \\
\hline \multicolumn{7}{|c|}{ Panel C. AR using CAPM as a benchmark } \\
\hline \multirow{3}{*}{ AR } & \multirow{2}{*}{$\mathrm{N}$} & \multirow{2}{*}{ Mean } & \multirow{2}{*}{ Std } & $d f$ & \multicolumn{2}{|c|}{ t-statistic } \\
\hline & & & & dI & Value & probability \\
\hline & 60 & 0.00550 & 0.012717 & 59 & 3.342 & $0.0000 * * *$ \\
\hline
\end{tabular}

Note. ${ }^{* * *}$ stands for statistical significance at the 1 percent level. 
In parametric t-test, the null hypothesis has been tested regards the average abnormal returns whether it is significantly different from zero based on the one-sample t-test. Table 7 summarized the one sample T-test results of abnormal return (AR) among the employed three benchmarks.

Table 7 reveals that the average abnormal return (AR) when Amman stock Exchange Index is employed as a benchmark is different from zero (0.01258). This difference is confirmed statistically with a P-value of $(0.0000)$. Therefore at (1\%) level of significance; the null hypothesis is rejected due to P-value which is less than (1\%) and the difference is significant.

The average abnormal return (AR) of the matching firms model (MF) is statistically different from zero (0.00348). Actually, this difference is confirmed statistically for abnormal return which has a p-value of $(0.0000)$. Therefore at a (1\%) level of significance; the null hypothesis is rejected due to $p$-value which is less than $(1 \%)$ and the difference is significant.

The table above also reveals that the average abnormal return (AR) once employed the capital assets pricing model (CAPM) is statistically different from zero (0.00550). This difference is confirmed statistically for abnormal return which has a p-value of $(0.0000)$, therefore at $(1 \%)$ level of significance. Thus, the null hypothesis is rejected.

\section{Simple Linear Regression Results (Test the Null Hypotheses $\mathrm{HO}_{4}, \mathrm{HO}_{5}, \mathrm{HO}_{6}$, and $\mathrm{HO}_{7}$ )}

This section deals with the listed IPOs firm characteristic and its relationship with abnormal return (AR) based on the benchmarks employed. The simple linear regression is used to determine, whether, or not, there is a relationship between each character (firm age, firm size, and size of offers, the sector that the firm belongs to, and the abnormal return (AR) for each benchmark employed. Table 8 represents the simple linear regression results.

Table 9. Simple linear regression of (AR) with company characteristics

\begin{tabular}{|c|c|c|c|c|c|c|c|c|c|}
\hline $\begin{array}{c}\text { Independent } \\
\text { variable property }\end{array}$ & $\begin{array}{c}\text { Dependent } \\
\text { variable }\end{array}$ & $\mathbf{R}$ & $\mathbf{R}^{2}$ & $\widehat{\alpha}$ & $\widehat{\boldsymbol{\beta}}$ & t-test & (a) Sig & F-test & (b) Sig \\
\hline \multirow{3}{*}{ Company size } & AR(ASEI) & $0.67 * *$ & 0.45 & -0.92 & 0.67 & 5.76 & 0.000 & 33.24 & 0.000 \\
\hline & AR(CAPM) & $0.48 * *$ & 0.24 & -1.86 & 0.48 & 4.49 & 0.000 & 20.18 & 0.000 \\
\hline & $\mathrm{AR}(\mathrm{MF})$ & $0.56 * *$ & 0.32 & -1.67 & 0.56 & 3.96 & 0.000 & 13.66 & 0.000 \\
\hline \multirow{3}{*}{ Company age } & AR (ASEI) & $0.55^{* *}$ & 0.31 & -0.78 & 0.55 & 5.31 & 0.000 & 14.22 & 0.000 \\
\hline & $\mathrm{AR}(\mathrm{CAPM})$ & $0.38 * *$ & 0.15 & -1.91 & 0.38 & 3.18 & 0.000 & 4.71 & 0.030 \\
\hline & $\mathrm{AR}(\mathrm{MF})$ & $0.67 * *$ & 0.45 & -1.77 & 0.32 & 2.11 & 0.040 & 8.52 & 0.020 \\
\hline \multirow{3}{*}{ Size of offers } & AR(ASEI) & $0.47 * *$ & 0.23 & -0.75 & 0.28 & 3.25 & 0.000 & 10.24 & 0.000 \\
\hline & $\mathrm{AR}(\mathrm{CAPM})$ & $0.34 * *$ & 0.12 & -1.72 & 0.34 & 5.17 & 0.000 & 17.29 & 0.002 \\
\hline & $\mathrm{AR}(\mathrm{MF})$ & $0.44 * *$ & 0.20 & -1.53 & 0.28 & 2.35 & 0.02 & 4.71 & 0.031 \\
\hline \multirow{3}{*}{$\frac{\text { Sector }}{\text { Financial firms }}$} & AR (ASEI) & $0.80 * *$ & 0.64 & 2.31 & 0.80 & 3.57 & 0.000 & 16.19 & 0.000 \\
\hline & $\mathrm{AR}(\mathrm{CAPM})$ & $0.66 * *$ & 0.44 & 0.81 & 0.66 & 6.10 & 0.000 & 10.21 & 0.000 \\
\hline & $\mathrm{AR}(\mathrm{MF})$ & $0.76 * *$ & 0.58 & 2.10 & 0.51 & 2.11 & 0.042 & 14.37 & 0.000 \\
\hline \multirow{3}{*}{ Industrial firms } & AR(ASEI) & $0.61 * *$ & 0.38 & -1.14 & 0.38 & 4.27 & 0.000 & 12.50 & 0.000 \\
\hline & $\mathrm{AR}(\mathrm{CAPM})$ & $0.37 * *$ & 0.14 & -1.86 & 0.37 & 2.09 & 0.045 & 8.81 & 0.000 \\
\hline & $\mathrm{AR}(\mathrm{MF})$ & $0.31 * *$ & 0.10 & -1.67 & 0.31 & 5.11 & 0.000 & 28.25 & 0.000 \\
\hline \multirow{3}{*}{ Service firms } & AR(ASEI) & $0.42 * *$ & 0.18 & -0.78 & 0.42 & 1.31 & 0.19 & 1.72 & 0.19 \\
\hline & $\mathrm{AR}(\mathrm{CAPM})$ & $0.45^{* *}$ & 0.21 & -1.91 & 0.28 & 3.27 & 0.000 & 16.12 & 0.000 \\
\hline & $\mathrm{AR}(\mathrm{MF})$ & $0.28 * *$ & 0.08 & -1.67 & 0.28 & 4.10 & 0.000 & 12.24 & 0.000 \\
\hline
\end{tabular}

Note. ${ }^{*}$ Stands for $1 \%$ level of significance.(a) represent the model ability to predict.(b) represent the validity of the model.

From the table above, it appears that the company size is positively correlated with abnormal return (AR), the $\mathrm{R}^{2}$ values are (45\%) when using (ASEI) as benchmark, which means that this independent variable could explain $45 \%$ of the variance of the abnormal return (AR) when using ASEI as a benchmark. However, the company size also explained $(24 \%, 32 \%)$ of the variance of the abnormal return (AR) when using capital assets pricing model (CAPM) and matching firms (MF) respectively as benchmarks. The model is highly statistically significant $(\mathrm{F}=33.24,20.18,13.66$, sig $=0.000,0.000,0.000)$. Therefore, the null hypothesis $(\mathrm{H} 04)$ is rejected at $5 \%$ level of significance. 
In respect to the second feature, which is (firm age) and its relationship with abnormal return (AR), it seems that the company age is also positively correlated with abnormal return (AR) against the three bench marks represented by R-values which are $(55 \%, 38 \%$, and $67 \%)$. This means that this independent variable explained $(31 \%, 15 \%$, and $45 \%)$ respectively of the variance of the abnormal return (AR) using (ASEI, CAPM, MF) as benchmarks.

However, the model here is also highly statistically significant as $(F=14.22,4.71,8.52, \operatorname{sig}=0.000,0.000,0.000)$. Thus, the null hypothesis $\left(\mathrm{HO}_{5}\right)$ is rejected at $5 \%$ level of significant. These findings are in line with the previous study results such as (Braik, 2010; Kurshed, 1999; Ritter, 1991).

In regards to (offer size), it is also positively correlated with abnormal return (AR). The R-values are (47\%, 34\%, and 44\%) respectively, when using (ASEI, CAPM, MF) as benchmarks. This characteristic as (independent variable) explained $(23 \%, 12 \%$, and $20 \%$ ) respectively of the variance of the abnormal return as a (dependent variable). The model is highly statistically significant as $(\mathrm{F}=10.24,17.29,4.71$, sig=0.000, 0.000, 0.000) at 5\%. These results about the size of offers and its relationships with listed IPOs firms performance do not correspond with previous findings such as (Braik, 2010), which found no relationship between the offers size and the long run performance of IPOs.

The last characteristic is the sector that the company belongs to. The results are summarized in the table above. They are similar to previous findings, which confirm that the sector where the company belongs to is positively correlated with abnormal return (AR). As shown in the table above, the financial firms are highly correlated with abnormal return against all benchmarks with $\mathrm{R}$-values $(80 \%, 66 \%$, and $76 \%$ ) respectively, which means that this type of firms is able to explain $(64 \%, 44 \%, 58 \%)$ of the variance of abnormal return (AR).

The model here is also highly statistically significant as $(\mathrm{F}=16.19,10.21,14.37$, sig=0.000, 0.000, 0.000). Based on the results related to this type of firms, it is recommended to invest in this type of firms because its long run performance is higher than other type of firms.

The Industrial firms also positively correlated with abnormal return (AR) for all benchmarks employed of R-values are $(61 \%, 37 \%$, and $31 \%)$. This type of firms explained $(38 \%, 14 \%$, and $10 \%)$ of the variance of (AR). The model is highly statistically significant as $(\mathrm{F}=12.50,8.81,28.25, \mathrm{sig}=0.000,0.000,0.000)$.

The last type of firms is the service firms which also positively correlated with abnormal return (AR). The R-values are $(42 \%, 45 \%, 28 \%)$ respectively for all the employed bench marks. This type of firms explained $(18 \%, 21 \%, 8 \%)$ of the variance of (AR). The model is also highly statistically significant when using only $(\mathrm{CAPM})$ and $(\mathrm{MF}$ as benchmarks where $(\mathrm{F}=16.12,12.24$, sig $=0.000,0.000)$. But it isn't statistically significant when employing (ASEI) as a benchmark, where $(\mathrm{F}=1.72, \mathrm{t}=1.31)$. In total, the null hypothesis $\left(\mathrm{H}_{6}\right)$ at $5 \%$ level of significance is rejected due to $\mathrm{P}$-values which are less than $5 \%$.

Table 10. Hypothesis testing results

\begin{tabular}{|c|c|c|c|c|}
\hline & & $\begin{array}{l}\text { Hypothesis } \\
\text { Number }\end{array}$ & The Null Hypothesis & Result \\
\hline \multirow{4}{*}{ Benchmark } & \multicolumn{4}{|c|}{ Benchmark number one: Amman Stock Exchange Index (ASEI) } \\
\hline & AR & $\mathrm{H} 01$ & $\begin{array}{l}\text { The abnormal return is not significantly different from zero once } \\
\text { applied (ASEI) as a benchmark. }\end{array}$ & Rejected \\
\hline & \multicolumn{4}{|c|}{ Benchmark number Two: Matching Firms (MF) } \\
\hline & AR & $\mathrm{H} 02$ & $\begin{array}{l}\text { The abnormal return is not significantly different from zero once } \\
\text { applied (MF) as a benchmark. }\end{array}$ & Rejected \\
\hline & \multicolumn{4}{|c|}{ Benchmark number Three: Capital Assets Pricing Model (CAPM) } \\
\hline Benchmark & AR & $\mathrm{H} 03$ & $\begin{array}{l}\text { The abnormal return is not significantly different from zero once } \\
\text { applied (CAPM) as a benchmark. }\end{array}$ & Rejected \\
\hline \multirow{4}{*}{$\begin{array}{l}\text { Listed Firm } \\
\text { properties }\end{array}$} & Company Size & & $\begin{array}{l}\text { There is no statistical significant relationship between the size of } \\
\text { the listed firm and its long run performance }\end{array}$ & Rejected \\
\hline & Company Age & & $\begin{array}{l}\text { There is no statistical significant relationship between the Age of } \\
\text { the listed firm and its long run performance }\end{array}$ & Rejected \\
\hline & Size of offers & H06 & $\begin{array}{l}\text { There is no statistical significant relationship between the size of } \\
\text { offers of the listed firm and its long run performance }\end{array}$ & Rejected \\
\hline & Company Sector & H07 & $\begin{array}{l}\text { There is no statistical significant relationship between the sector of } \\
\text { the listed firm and its long run performance }\end{array}$ & Rejected \\
\hline
\end{tabular}




\section{Conclusion}

This study investigated the long run abnormal performance of Jordanian IPOs during the period from $1^{\text {st }}$ January 1993 to $31^{\text {st }}$ December 2011. The study used the event study approach, and employed three benchmarks: Amman stock exchange index (ASEI), Matching Firms (MF), and the Capital Assets Pricing Model (CAPM). Numerous studies document significant abnormal returns after corporate events, and ascribe the returns to the events themselves. However, as Loughran and Ritter (2000) observe, it is of interest to assess whether any particular pattern in returns is unique or is a manifestation of other return regularities that are known to exist in the stock markets. We focus in particular on the "abnormal return" (AR) method where accumulated returns to event firms are compared to accumulated returns of Index, typically matched on the basis of firm size, age, sector, and offer size. The findings of this study are in line with the results of many previous studies conducted the long run underperformance of IPOs, like (Ritter, 1991; Levis, 1993; Loughran \& Ritter, 1995; Drobetz et al., 2005). These studies summarized and highlighted important empirical regularities; that the long run abnormal returns are often quite negative.

This study has provided further evidence of the long run underperformance of Jordanian IPOs phenomenon, and this underperformance is sensitive to the benchmarks employed.

Regarding to the relationship between some properties of the listed Jordanian IPOs (firm age, firm size, firm sector, offers size) and the abnormal return (AR) against the three benchmarks employed. The study results showed that all of these properties are positively correlated with abnormal return (AR). Moreover, by analyzing the Jordanian IPOs sectors, the results showed that the financial IPOs performing better than other types of IPOs in the long run. But they are still underperformed against the benchmarks. In this aspect of the study, the results are consistent with the finding of (Braik, 2010) that found a positive relationship between the firm age and its long run performance, but contradicts the same study regarding the offers size and its relationship with long run performance. Our study does not find any relationship between them. Also the study results are consistent with the findings of (Khurshed, 1999) which found there is a positive relationship between the firm size and its long run performance.

\section{References}

Agarwal, A. (2012). The Impact of Rights Issue on Stock Returns in India. The Journal of Asia-Pacific Finance and Accounting Review, 1(1), 5-16.

Agarwal, R., \& Conroy, P. (2000). Price discovery in initial public offerings, and the role of the lead underwriter. Journal of Finance, 55, 2903-29022. http://dx.doi.org/10.1111/0022-1082.00312

Amman Stock Exchange Reports. (2011). Retrieved from http:// www.ase.com.jo

Amman Stock Exchange Reports. (2012). Retrieved from http:// www.ase.com.jo

Barber, M., \& Lyon, D. (1997). Detecting Lon run abnormal stock returns: The empirical power and specification of test statistics. Journal of Financial Economics, 43, 341-372. http://dx.doi.org/10.1016/S0304-405X(96)00890-2

Barber, M., Lyon, D., \& Tasia, C. (1999). Improved methods for test of long run abnormal stock returns. Journal of Finance, 27(1).

Braik, F. (2010). An empirical investigation of initial public offerings price performances-evidence from Jordanian stock market. Unpublished thesis, mutah university, 2010.

Brav, A., \& Gompers, P. (1997). Myth or reality? The long run under performance of initial public offerings: Evidence from venture and no venture capital - backed companies. Journal of Finance, 52, 1791-1821. http://dx.doi.org/10.1111/j.1540-6261.1997.tb02742.x

Carter, B., Frederik, H., Ajai, K., \& Siugh. (1998). Underwriter reputation, initial return, and long run performance of IPO stocks. Journal of Finance, 53, 285-311. http://dx.doi.org/10.1111/0022-1082.104624

Desai, H., \& Jain, P. (1997). Long run common stock returns following splits and reverse split. Journal of Business, 70, 409-433. http://dx.doi.org/10.1086/209724

Dimovski, W., \& Brooks, R. (2008), The Under pricing of gold mining initial public offerings. Journal of International Business and Finance, 22, 1-16. http://dx.doi.org/10.1016/j.ribaf.2006.11.002

Dimson, E., \& Paul, M. (1986). Event Study Methodologies and the Size Effect. Journal of Financial Economics, 17, 113-142. http://dx.doi.org/10.1016/0304-405X(86)90008-5 
Drobetz, W. K. \& Walchli, M. (2005). Long run performance of initial public offerings: The evidence for Switzerland. Business Review, 57, 253-275.

Espenlaub, S., \& Gregory, A. (2000). Re-assessing the long term underformance of UK initial public offerings. European Financial Management, 6, 319-342. http://dx.doi.org/10.1111/1468-036X.00127

Espenlaub, S., \& Tonks, I. (1998). Post initial public offerings directors, sales and reissuing activity: An empirical test of IPOs signaling models. Working Paper, School of Accounting and Finance, University of Manchester.

Fama, E., \& French, K. (1992). The crose-section of expected stock returns. Journal of Finance, XLVII(2), 156-171.

Fama, F., \& French, R. (1996). Multi factor explanation of asset pricing anomalies. Journal of Finance, 51, 55-84. http://dx.doi.org/10.1111/j.1540-6261.1996.tb05202.x

Fama, F., \& French, R. (1998). Market efficiency, long term returns and behavioral finance. Journal of Financial Economics, 4, 283-306. http://dx.doi.org/10.1016/S0304-405X(98)00026-9

Gomper, P., \& Lerner, J. (1999). Conflict of interest in the issuance of public securities: Evidence from venture capital. Journal of Law and Economics, 42, 1-28. http://dx.doi.org/10.1086/467416

Grogory, A., Cuermat, C., \& AL-Shawawreh, F. (2010). UK IPOs: Long run returns, behavioral timing and pseudo timing. Journal of Business Finance and Accounting, 37(5-6), 612-647. http://dx.doi.org/10.1111/j.1468-5957.2010.02182.x

Ibbotson, R., \& Jaffe, J. (1975). Hot issue markets. Journal of Finance, 30, 1027-1042.

Ikenberry, D., Rankine, G., \& Stice, E. (1996). What do stock split really signal. Journal of Financial and Quantitive Analysis, 31, 357-377. http://dx.doi.org/10.2307/2331396

Jordan Securities Commission Reports. (2011). Retrieved from http://www.jsc.gov.jo

Khurshed, A. (1999). The long run performance of IPOs. Managerial Finance, 33(6), 401-419. http://dx.doi.org/10.1108/03074350710748759

Kooli, M., Suret, J., \& Francois, J. (2004). Do IPOs really underperform in the long run? New evidence from the Canadian market. Journal of Finance, 26, 128-147.

Levis, M. (1993). The long run performance of initial public offerings: The UK experience 1980-1988. Journal of Financial Management, 22, 24-41. http://dx.doi.org/10.2307/3665963

Loughran, T., \& Ritter, J. (1995). The new issues puzzle. Journal of Finance, 50, 23-51. http://dx.doi.org/10.1111/j.1540-6261.1995.tb05166.x

Mitchell, M., \& Stafford, E. (2000). Managerial decisions and long term stock price performance. Journal of Business, 73, 287-320. http://dx.doi.org/10.1086/209645

Owen, A., \& Ann, J. (2008). The pricing and impact of rights issues of equity in Australia. Applied of Financial Economics, 18, 1147-1160. http://dx.doi.org/10.1080/09603100701537706

Ritter, J. (1991). The Long run performance of initial public offerings. Journal of Finance, 46, 3-27. http://dx.doi.org/10.1111/j.1540-6261.1991.tb03743.x

Sapusek, A. (2000). Bench mark- sensitivity of IPO long run performance: An empirical study for Germany. Business Review, 52, 374-405.

\section{Copyrights}

Copyright for this article is retained by the author(s), with first publication rights granted to the journal.

This is an open-access article distributed under the terms and conditions of the Creative Commons Attribution license (http://creativecommons.org/licenses/by/3.0/). 